\title{
A Fluorescent Sensor for Zinc Detection and Removal Based on Core-Shell Functionalized $\mathrm{Fe}_{3} \mathrm{O}_{4} @ \mathrm{SiO}_{2}$ Nanoparticles
}

\author{
Yaohui Xu, ${ }^{1,2}$ Yang Zhou, ${ }^{1,2}$ Wenhui Ma, ${ }^{1,2}$ and Shixing Wang ${ }^{1}$ \\ ${ }^{1}$ Faculty of Metallurgical and Energy Engineering, Kunming University of Science and Technology, Kunming 650093, China \\ ${ }^{2}$ National Engineering Laboratory for Vacuum Metallurgy, Kunming University of Science and Technology, Kunming 650093, China \\ Correspondence should be addressed to Yang Zhou; zhouyangnano@163.com
}

Received 11 December 2012; Accepted 5 January 2013

Academic Editor: Tao Chen

Copyright (c) 2013 Yaohui Xu et al. This is an open access article distributed under the Creative Commons Attribution License, which permits unrestricted use, distribution, and reproduction in any medium, provided the original work is properly cited.

\begin{abstract}
The magnetic $\mathrm{Fe}_{3} \mathrm{O}_{4} @ \mathrm{SiO}_{2}$ nanoparticles (NPs) functionalized with 8-chloroacetylaminoquinoline as a fluorescent sensor for detection and removal of $\mathrm{Zn}^{2+}$ have been synthesized. The core-shell structures of the nanoparticles and chemical composition have

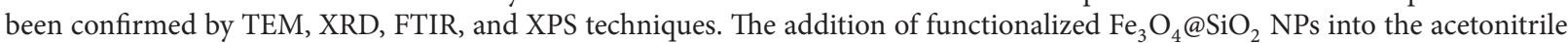
solution of $\mathrm{Zn}^{2+}$ had an effect of visual color change as well as significant fluorescent enhancement. High-saturated magnetizations (24.7 emu/g) of functionalized $\mathrm{Fe}_{3} \mathrm{O}_{4} @ \mathrm{SiO}_{2} \mathrm{NPs}$ could help to separate the metal ions from the aqueous solution. The magnetic sensor exhibited high removal efficiency towards $\mathrm{Zn}^{2+}(92.37 \%)$. In this work, we provided an easy and efficient route to detect $\mathrm{Zn}^{2+}$ and simultaneously remove $\mathrm{Zn}^{2+}$.
\end{abstract}

\section{Introduction}

Zinc ion, as biologically important metal ions, plays a vital biological role in various pathophysiologic processes, such as gene expression, cell apoptosis, enzymatic adjustment, and neurotransmission, because of its structural properties [1-3]. Toxic in excess or absence, the break-up of zinc ion homeostasis may cause pathology of intellectual development and other neurological problems such as Alzheimer's and Parkinson's diseases $[4,5]$. Therefore, the analytical approaches to detect $\mathrm{Zn}^{2+}$ have been studied intensively. So far, many selective smart-molecular fluorescent probes targeting $\mathrm{Zn}^{2+}$ have been reported, that are mostly based on quinoline, fluorescein, benzazole, or fluorophores [6-10]. For example, Li et al. [11] reported a "switching on" fluorescent chemodosimeter of selectivity to $\mathrm{Zn}^{2+}$ and its application to MCF-7 cells. Lee et al. [12] also synthesized and evaluated two new ratiometric chemosensors for the quantification of potentially toxic free $\mathrm{Zn}^{2+}$ ions in aqueous solutions. Recently, Chen and $\mathrm{Li}$ et al. [13] synthesized a new fluorescent chemosensor based on a helical imide as fluorophore and a cyclen moiety as ionophore, which not only showed enhanced fluorescent responses in the presence of $\mathrm{Zn}^{2+}, \mathrm{Cd}^{2+}$, and $\mathrm{Hg}^{2+}$, but also could simultaneously and selectively distinguish the three cations in a simulated physiological condition with the help of cysteine as an auxiliary reagent. Moreover, Ding et al. [14] investigated selective and sensitive "turn-on" fluorescent $\mathrm{Zn}^{2+}$ sensors based on di- and tripyrrins with readily modulated emission wavelengths. However, their chemosensors were unsuitable or inconvenient for the separation, removal, and enrichment of target species or in rapid screening applications.

Over the past decade, the modification of small molecular fluorescent probes on the surface of nanostructured materials has been attracting significant attention [15-18]. Among these nanostructured materials, core-shell $\mathrm{Fe}_{3} \mathrm{O}_{4} @ \mathrm{SiO}_{2} \mathrm{NPs}$ have been widely favored in biological and environmental applications [19-21]. First of all, the magnetic $\mathrm{Fe}_{3} \mathrm{O}_{4} \mathrm{NPs}$ as core in the $\mathrm{Fe}_{3} \mathrm{O}_{4} @ \mathrm{SiO}_{2}$ NPs would facilitate the magnetic separation and recuperation from the detection system within the magnetic field. Moreover, the coating of silica would not only stabilize the magnetic nanocore completely, but also provide sites greatly for surface modification [22-24]. In addition, due to more advantages of silica, such as nontoxicity, biocompatibility chemical inertness, no swelling, and transparency, it is a possible option to develop the nontoxic, 


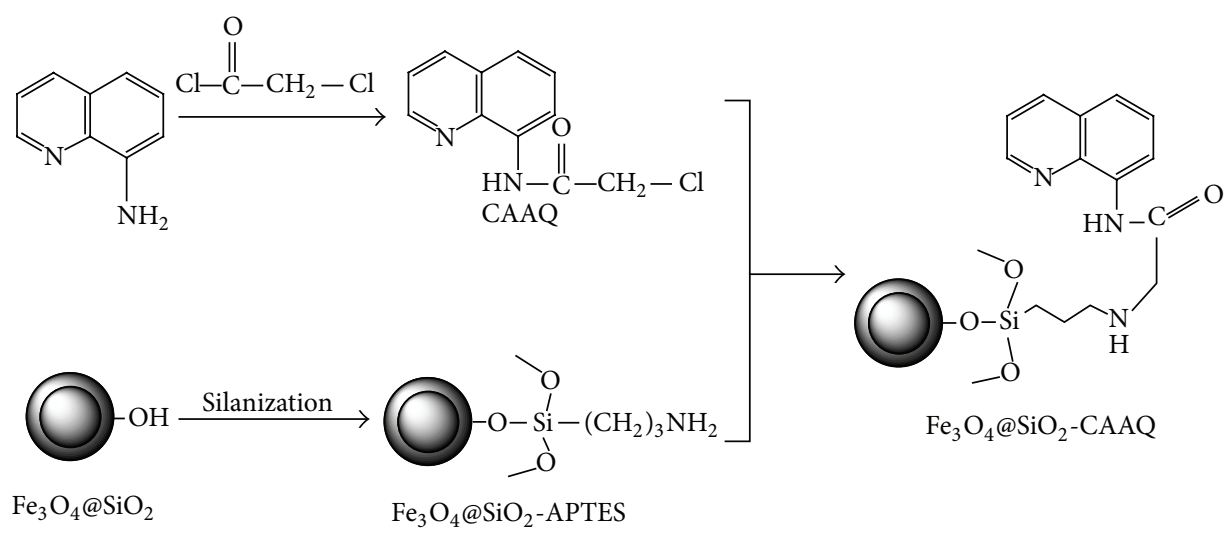

Scheme 1: The synthesis of CAAQ and the functionalization of $\mathrm{Fe}_{3} \mathrm{O}_{4} @ \mathrm{SiO}_{2}-\mathrm{CAAQ}$.

biocompatible, and recoverable $\mathrm{Zn}^{2+}$-selective fluorescent sensors on $\mathrm{Fe}_{3} \mathrm{O}_{4} @ \mathrm{SiO}_{2}$ NPs surface.

In this work, 8-chloroacetylaminoquinoline (CAAQ) was synthesized and covalently linked to $\mathrm{Fe}_{3} \mathrm{O}_{4} @ \mathrm{SiO}_{2} \mathrm{NPs}$ surface to establish an efficient system for the detection and removal of $\mathrm{Zn}^{2+}$ (labeled as $\mathrm{Fe}_{3} \mathrm{O}_{4} @ \mathrm{SiO}_{2}-\mathrm{CAAQ}$ ). The general synthetic strategies and the functionalization of $\mathrm{Fe}_{3} \mathrm{O}_{4} @ \mathrm{SiO}_{2} \mathrm{NPs}$ are shown in Scheme 1.

\section{Experimental Section}

2.1. Materials. Ferric chloride hexahydrate $\left(\mathrm{FeCl}_{3} \cdot 6 \mathrm{H}_{2} \mathrm{O}\right.$, $>98 \%)$, ferrous chloride tetrahydrate $\left(\mathrm{FeCl}_{2} \cdot 4 \mathrm{H}_{2} \mathrm{O},>99 \%\right)$, dichloromethane (DCM), ammonium hydroxide (28 wt\%), tetraethyl orthosilicate (TEOS), and potassium carbonate were obtained from Sinopharm Chemical Reagent Tianjin Co. Ltd. 8-Aminoquinoline, chloroacetyl chloride, triethylamine (TEA), and 3-aminopropyltriethoxysilane (APTES) were purchased from Alfa Aesar and Aladdin Co. Ltd.

2.2. Synthesis. The synthesis of 8-chloroacetylaminoquinoline (CAAQ) was based on the pervious report [25]. 8Aminoquinoline $(0.95 \mathrm{~g}, 6.6 \mathrm{mmol})$ and $1 \mathrm{~mL}$ TEA were mixed in $50 \mathrm{~mL} \mathrm{DCM}$ in an ice bath for $30 \mathrm{~min}$. Then, chloroacetyl chloride $(0.6 \mathrm{~mL}, 7.5 \mathrm{mmol})$ was added dropwise. The mixture was kept in darkness with continuous magnetic stirring for $48 \mathrm{~h}$ at room temperature. After that, the solvent was evaporated and the crude products were purified by silica gel column chromatography (petroleum ether/ethylacetate $=3: 1) .{ }^{1} \mathrm{HNMR}\left(\mathrm{CDCl}_{3}, 400 \mathrm{MHz}\right): \delta 10.7$ $(\mathrm{s}, 1 \mathrm{H}),, 8.4(\mathrm{~m}, 1 \mathrm{H}), 8.6(\mathrm{~m}, 1 \mathrm{H}), 8.9(\mathrm{~m}, 1 \mathrm{H}), 7.7(\mathrm{~m}, 1 \mathrm{H}), 4.5$ (s, 2H).

2.3. Preparation and Surface Modification of $\mathrm{Fe}_{3} \mathrm{O}_{4} @ \mathrm{SiO}_{2}$ NPs. $\mathrm{Fe}_{3} \mathrm{O}_{4}$ NPs were prepared according to our previous report [26]. $\mathrm{FeCl}_{2} \cdot 4 \mathrm{H}_{2} \mathrm{O}(2 \mathrm{~g}, 0.01 \mathrm{~mol})$ and $\mathrm{FeCl}_{3} \cdot 6 \mathrm{H}_{2} \mathrm{O}$ $(5.4 \mathrm{~g}, 0.02 \mathrm{~mol})$ were dissolved in $120 \mathrm{~mL}$ of deionized water. $\mathrm{NH}_{3} \cdot \mathrm{H}_{2} \mathrm{O}(60 \mathrm{~mL}, 28 \mathrm{wt} \%)$ was added under vigorous mechanical stirring. The color of the suspension turned black immediately. Afterward, the mixture was kept at $70^{\circ} \mathrm{C}$ for $30 \mathrm{~min}$. The mechanical stirring and nitrogen atmosphere were carried out throughout the reaction. After cooling down, the precipitated powders were collected by magnetic separation and washed with deionized water. Subsequently, trisodium citrate $(150 \mathrm{~mL}, 20 \mathrm{mmol} / \mathrm{L})$ was acceded to $\mathrm{Fe}_{3} \mathrm{O}_{4}$ NPs under vigorous mechanical stirring for $12 \mathrm{~h}$ under nitrogen atmosphere at room temperature. Finally, the citratefunctionalized $\mathrm{Fe}_{3} \mathrm{O}_{4} \mathrm{NPs}$ were washed with deionized water.

The core-shell $\mathrm{Fe}_{3} \mathrm{O}_{4} @ \mathrm{SiO}_{2}$ NPs were synthesized by a sol-gel process though the hydrolysis and condensation of TEOS in ethanol and ammonia mixture. Briefly, $0.56 \mathrm{~g}$ citrate-functionalized $\mathrm{Fe}_{3} \mathrm{O}_{4} \mathrm{NPs}$ and $\mathrm{NH}_{3} \cdot \mathrm{H}_{2} \mathrm{O}(5.0 \mathrm{~mL}$, $28 \mathrm{wt} \%$ ) were stirred in a flask charged with $120 \mathrm{~mL}$ ethanol. Afterward, $4.0 \mathrm{~mL}$ TEOS was added dropwise. The mixture was kept at room temperature for $8 \mathrm{~h}$ under $\mathrm{N}_{2}$ with violent mechanical stirring. The products were collected with a magnet and washed with ethanol and toluene.

The amino-functionalized $\mathrm{Fe}_{3} \mathrm{O}_{4} @ \mathrm{SiO}_{2} \mathrm{NPs}$ were synthesized by a silanization reaction. Namely, $0.8 \mathrm{~g} \mathrm{Fe}_{3} \mathrm{O}_{4} @ \mathrm{SiO}_{2}$ NPs and $80 \mathrm{~mL}$ toluene were stirred to form a homogeneous suspension, to which APTES $(3.46 \mathrm{~mL}, 15 \mathrm{mmol})$ was added using a syringe. The reaction mixture was kept at $90^{\circ} \mathrm{C}$ for $24 \mathrm{~h}$ under $\mathrm{N}_{2}$ with vigorous mechanical stirring. The obtained amino-group immobilized $\mathrm{Fe}_{3} \mathrm{O}_{4} @ \mathrm{SiO}_{2} \mathrm{NPs}$ (labeled as $\mathrm{Fe}_{3} \mathrm{O}_{4} @ \mathrm{SiO}_{2}$-APTES) were collected by magnetic separation and washed with ethanol and $\mathrm{CH}_{3} \mathrm{CN}(2 \times 50 \mathrm{~mL})$.

The as-prepared $\mathrm{Fe}_{3} \mathrm{O}_{4} @ \mathrm{SiO}_{2}$-APTES NPs, 0.6 g CAAQ and $0.08 \mathrm{~g} \mathrm{~K}_{2} \mathrm{CO}_{3}$ as catalyst were mixed into $80 \mathrm{~mL} \mathrm{CH}_{3} \mathrm{CN}$. The mixture was stirred at $60^{\circ} \mathrm{C}$ for $24 \mathrm{~h}$ under nitrogen atmosphere. After reaction and cooling down to room temperature, the obtained 8-chloroacetylaminoquinoline functionalized $\mathrm{Fe}_{3} \mathrm{O}_{4} @ \mathrm{SiO}_{2} \mathrm{NPs}$ (labeled as $\mathrm{Fe}_{3} \mathrm{O}_{4} @ \mathrm{SiO}_{2}-\mathrm{CAAQ}$ ) were magnetically separated and washed with $\mathrm{CH}_{3} \mathrm{CN}$ and ethanol $(2 \times 50 \mathrm{~mL})$ in turn.

2.4. Characterization. The morphology and size of $\mathrm{Fe}_{3} \mathrm{O}_{4} @$ $\mathrm{SiO}_{2}$ NPs were studied by transmission electron microscopy (TEM, JEM-2100). The structural properties of $\mathrm{Fe}_{3} \mathrm{O}_{4} @ \mathrm{SiO}_{2}$ NPs were studied by X-ray diffraction (XRD, RIGAKU $\mathrm{D} / \mathrm{MAX}-2400)$. The variation of function groups on $\mathrm{Fe}_{3} \mathrm{O}_{4} @ \mathrm{SiO}_{2} \mathrm{NPs}$ was obtained with Fourier transform infrared spectra (FT-IR, EQUINOX55). Proton nuclear magnetic resonance $\left({ }^{1} \mathrm{H}-\mathrm{NMR}\right)$ spectra were recorded using a Bruker AV 400 spectrometer. The C1s and N1s 


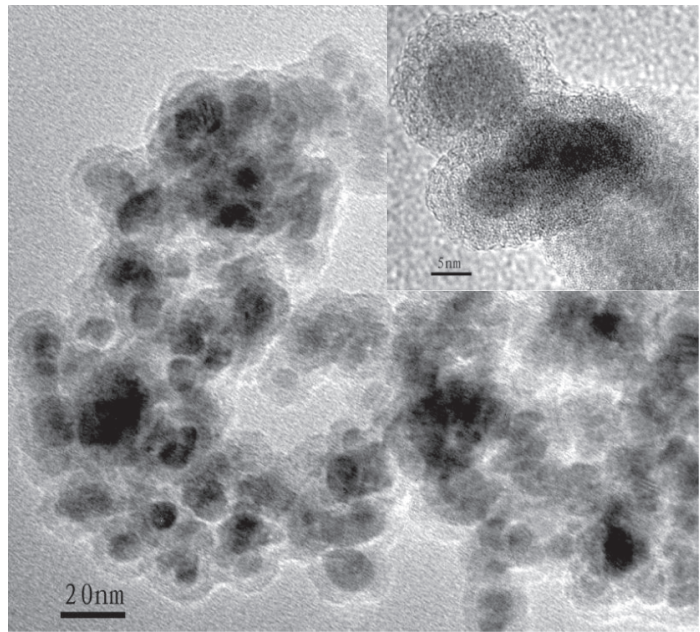

(a)

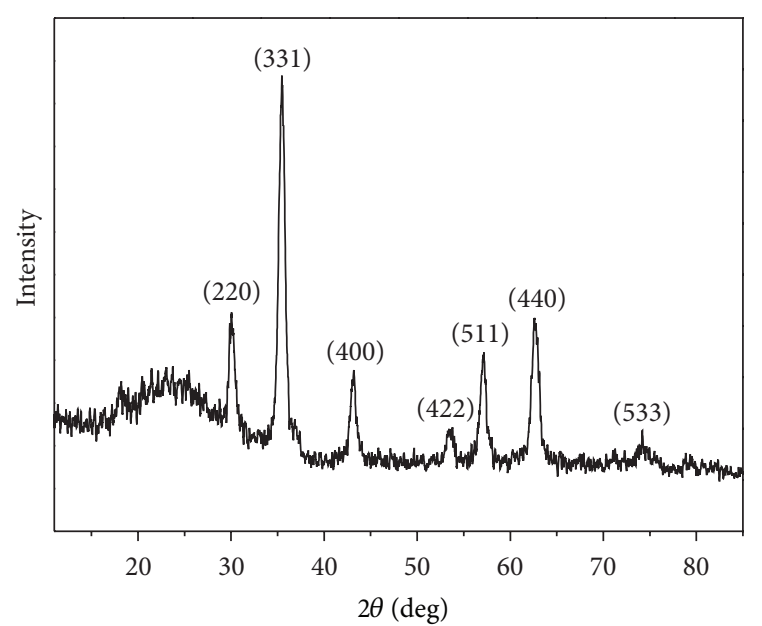

(b)

Figure 1: TEM images (a) and XRD pattern (b) of $\mathrm{Fe}_{3} \mathrm{O}_{4} @ \mathrm{SiO}_{2} \mathrm{NPs}$.

curve fitting of $\mathrm{Fe}_{3} \mathrm{O}_{4} @ \mathrm{SiO}_{2}$-CAAQ NPs were performed by X-ray photoelectron spectroscopy (XPS, ESCALab220i$\mathrm{XL}$ ). The magnetic properties of $\mathrm{Fe}_{3} \mathrm{O}_{4} @ \mathrm{SiO}_{2}$-CAAQ were obtained by using a vibrating sample magnetometer (VSM, Lakeshore 7307). Atomic absorption spectrum (AAS) was implemented by Shimadzu AA-6800 atomic absorption spectrophotometer. UV-vis spectra were recorded on a TU-1901 spectrophotometer.

\section{Results and Discussion}

The TEM images and XRD pattern of $\mathrm{Fe}_{3} \mathrm{O}_{4} @ \mathrm{SiO}_{2}$ NPs were shown in Figure 1. The average diameter of magnetic silica NPs was about $22 \mathrm{~nm}$ (Figure 1(a)). And from Figure 1(a), we can see clearly that the $\mathrm{Fe}_{3} \mathrm{O}_{4} @ \mathrm{SiO}_{2} \mathrm{NPs}$ have uniform spherical morphology. The inset in Figure 1(a) was the HRTEM image of $\mathrm{Fe}_{3} \mathrm{O}_{4} @ \mathrm{SiO}_{2} \mathrm{NPs}$, which demonstrated the obvious core-shell structure of magnetic silica NPs. In Figure 1(b), the sharp peaks at $2 \theta=30-80^{\circ}$ can be assigned to the (220), (311), (400), (422), (511), (440), and (533), which agreed well with the crystallographic planes of $\mathrm{Fe}_{3} \mathrm{O}_{4}$. Meanwhile, the broad featureless peak at $2 \theta=20-30^{\circ}$ was consistent with the amorphous state of the $\mathrm{SiO}_{2}$ shells, which proved the coating of silica on magnetite nanoparticles.

The variation of functional groups on $\mathrm{Fe}_{3} \mathrm{O}_{4} @ \mathrm{SiO}_{2} \mathrm{NPs}$ was characterized by FT-IR (Figure 2). The peaks for all samples at 3439,1083 , and $586 \mathrm{~cm}^{-1}$ were corresponded to the O$\mathrm{H}, \mathrm{Si}-\mathrm{O}$, and $\mathrm{Fe}-\mathrm{O}$. For $\mathrm{Fe}_{3} \mathrm{O}_{4} @ \mathrm{SiO}_{2}$-APTES, the $-\left(\mathrm{CH}_{2}\right)_{n^{-}}$ group was confirmed by $\mathrm{C}-\mathrm{H}$ stretching at $2933 \mathrm{~cm}^{-1}$ and the $\mathrm{C}-\mathrm{H}$ scissoring vibration at $1393 \mathrm{~cm}^{-1}$ (Figure 2(b)). For $\mathrm{Fe}_{3} \mathrm{O}_{4} @ \mathrm{SiO}_{2}$-CAAQ (Figure 2(c)), new absorption peaks appeared at $1682 \mathrm{~cm}^{-1}\left(\mathrm{C}=\mathrm{O}\right.$ bond), $1618 \mathrm{~cm}^{-1}$ ( $\mathrm{C}=\mathrm{N}$ bond), and $1487 \mathrm{~cm}^{-1}$ (N-H bond), which implied that the CAAQ was successfully bonded on the surface of $\mathrm{Fe}_{3} \mathrm{O}_{4} @ \mathrm{SiO}_{2}$ APTES NPs through amino group.

XPS spectra of $\mathrm{Fe}_{3} \mathrm{O}_{4} @ \mathrm{SiO}_{2}$ and $\mathrm{Fe}_{3} \mathrm{O}_{4} @ \mathrm{SiO}_{2}$-CAAQ were shown in Figure 3 . The wide-scan spectrum of
$\mathrm{Fe}_{3} \mathrm{O}_{4} @ \mathrm{SiO}_{2} \mathrm{NPs}$ (Figure 3(a)) was dominated by the signals of $\mathrm{Fe}, \mathrm{O}, \mathrm{C}$, and $\mathrm{Si}$ element. Compared with the widescan spectrum of $\mathrm{Fe}_{3} \mathrm{O}_{4} @ \mathrm{SiO}_{2} \mathrm{NPs}, \mathrm{Fe}_{3} \mathrm{O}_{4} @ \mathrm{SiO}_{2}$-CAAQ NPs (Figure 3(b)) revealed the new obvious peak of $\mathrm{N}$ element. In Figure 3(c), the Cls core-level spectrum of $\mathrm{Fe}_{3} \mathrm{O}_{4} @ \mathrm{SiO}_{2}$ CAAQ can be curve-fitted into three peak components with binding energies at about 288.2, 285.5, and $284.4 \mathrm{eV}$, attributable to the $\mathrm{N}-\mathrm{C}=\mathrm{O}, \mathrm{C}-\mathrm{N}$, and $\mathrm{C}-\mathrm{H}$ species, respectively. In Figure 3(d), the N1s core-level spectrum can be curve-fitted into two peak components with binding energies at about 399.8 and $399.1 \mathrm{eV}$, which were ascribed to the $\mathrm{N}-$ $\mathrm{C}=\mathrm{O}$ and $\mathrm{C}-\mathrm{N}$ species, respectively.

Figure 4 showed the magnetic properties of $\mathrm{Fe}_{3} \mathrm{O}_{4} @ \mathrm{SiO}_{2}$ and $\mathrm{Fe}_{3} \mathrm{O}_{4} @ \mathrm{SiO}_{2}-\mathrm{CAAQ} \mathrm{NPs}$. From Figure 4, we can see that the saturated magnetizations of $\mathrm{Fe}_{3} \mathrm{O}_{4} @ \mathrm{SiO}_{2}$ and $\mathrm{Fe}_{3} \mathrm{O}_{4} @ \mathrm{SiO}_{2}$-CAAQ NPs were 38.1 and $24.7 \mathrm{emu} / \mathrm{g}$ at $25^{\circ} \mathrm{C}$, and neither remanence nor coercivity was observed, which indicated that the $\mathrm{Fe}_{3} \mathrm{O}_{4} @ \mathrm{SiO}_{2}$ and $\mathrm{Fe}_{3} \mathrm{O}_{4} @ \mathrm{SiO}_{2}$-CAAQ were superparamagnetic nanoparticles. Thus, it provided an easy and efficient route to separate particles from a suspension system under an external magnetic field. The decrease of the saturated magnetization for functionalized magnetic silica nanoparticles was mainly attributed to the contribution of the volume of the nonmagnetic coating layer to the total sample volume. The strong magnetic sensitivity of the magnetic nanohybrid was confirmed by the inset in Figure 4 , which showed the complete magnetic separation by supplying an external magnetic field near the $\mathrm{Fe}_{3} \mathrm{O}_{4} @ \mathrm{SiO}_{2}-$ CAAQ NPs suspension system. The $\mathrm{Fe}_{3} \mathrm{O}_{4} @ \mathrm{SiO}_{2}$-CAAQ NPs are magnetic, so they can easily be removed by applying an external magnetic field after binding with $\mathrm{Zn}$ ions in aqueous solution, which makes them recyclable. Actually this is an important property for decontaminating agent.

The atomic absorption spectrum (AAS) was employed to monitor the variation of zinc ions before and after $\mathrm{Fe}_{3} \mathrm{O}_{4} @ \mathrm{SiO}_{2}$-CAAQ treatment. Figure 5 showed the effective removal of $\mathrm{Fe}_{3} \mathrm{O}_{4} @ \mathrm{SiO}_{2}$-CAAQ NPs for $\mathrm{Zn}^{2+}$ in aqueous 


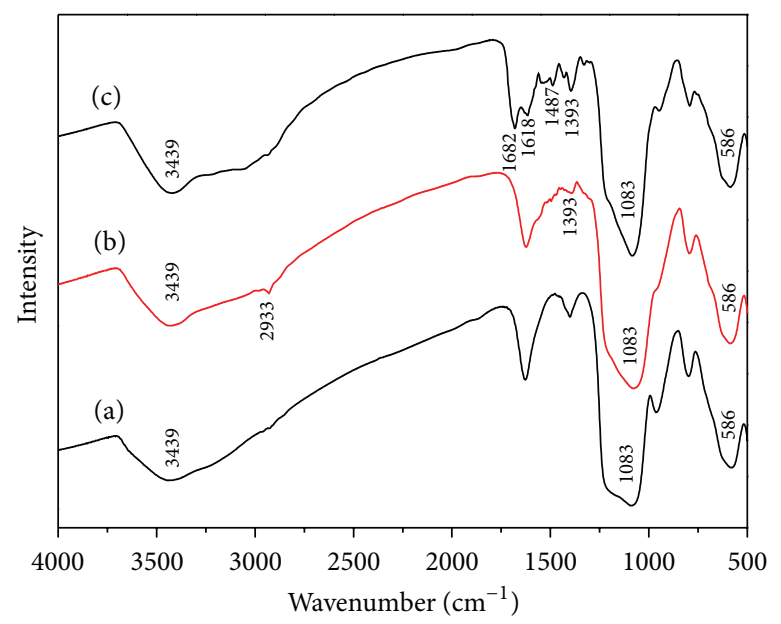

Figure 2: FT-IR spectra of (a) $\mathrm{Fe}_{3} \mathrm{O}_{4} @ \mathrm{SiO}_{2}$, (b) $\mathrm{Fe}_{3} \mathrm{O}_{4} @ \mathrm{SiO}_{2}$-APTES, and (c) $\mathrm{Fe}_{3} \mathrm{O}_{4} @ \mathrm{SiO}_{2}-\mathrm{CAAQ} \mathrm{NPs}$.

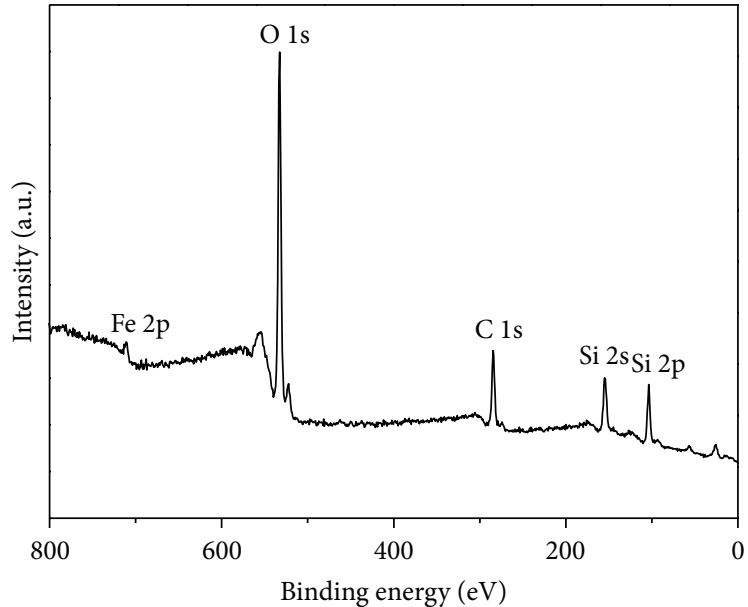

(a)

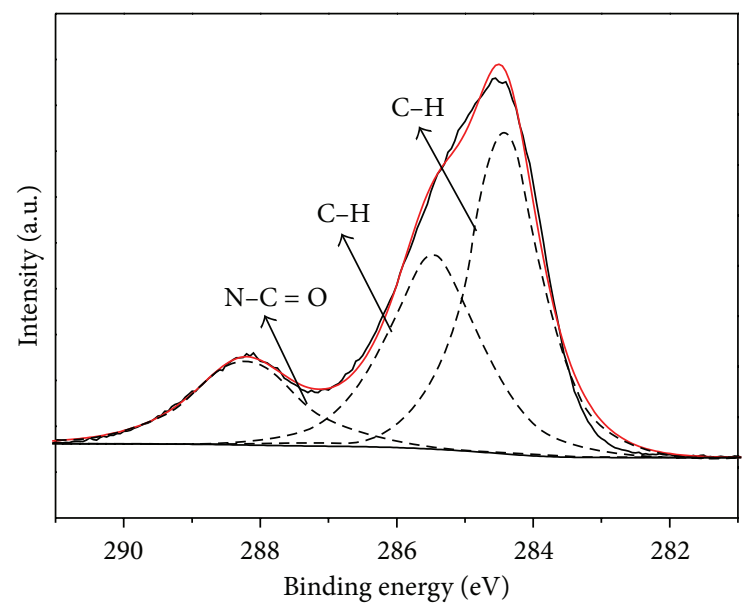

(c)

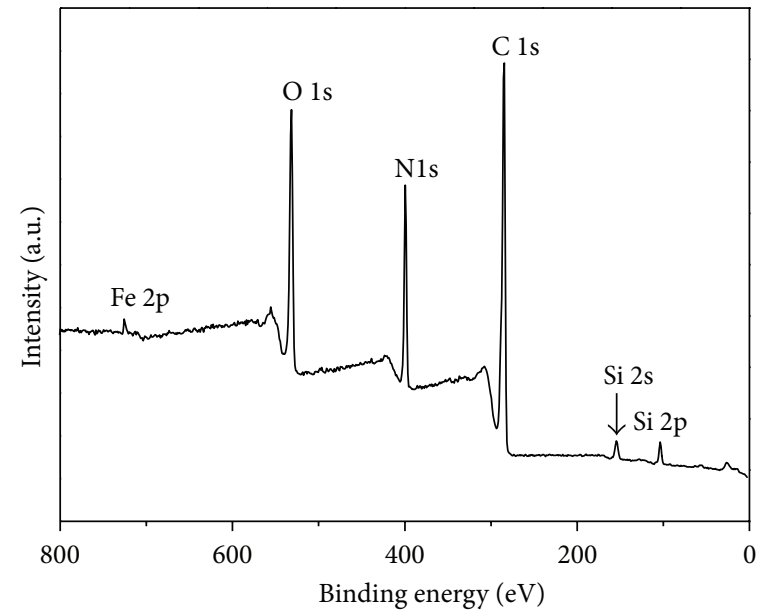

(b)

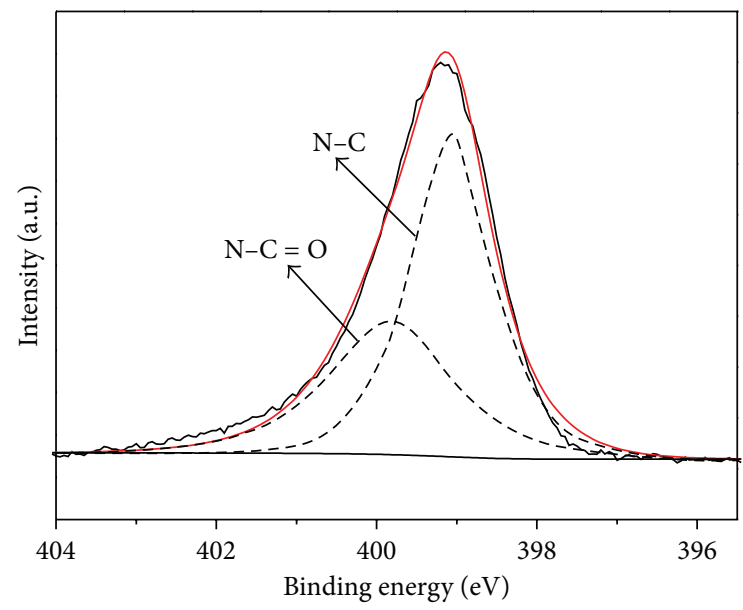

(d)

Figure 3: Wide scan of $\mathrm{Fe}_{3} \mathrm{O}_{4} @ \mathrm{SiO}_{2}$ (a) and $\mathrm{Fe}_{3} \mathrm{O}_{4} @ \mathrm{SiO}_{2}$-CAAQ NPs (b), Cls core-level (c) and Nls core-level (d) spectra of Fe $\mathrm{O}_{4} @ \mathrm{SiO}_{2}$ CAAQ NPs. 


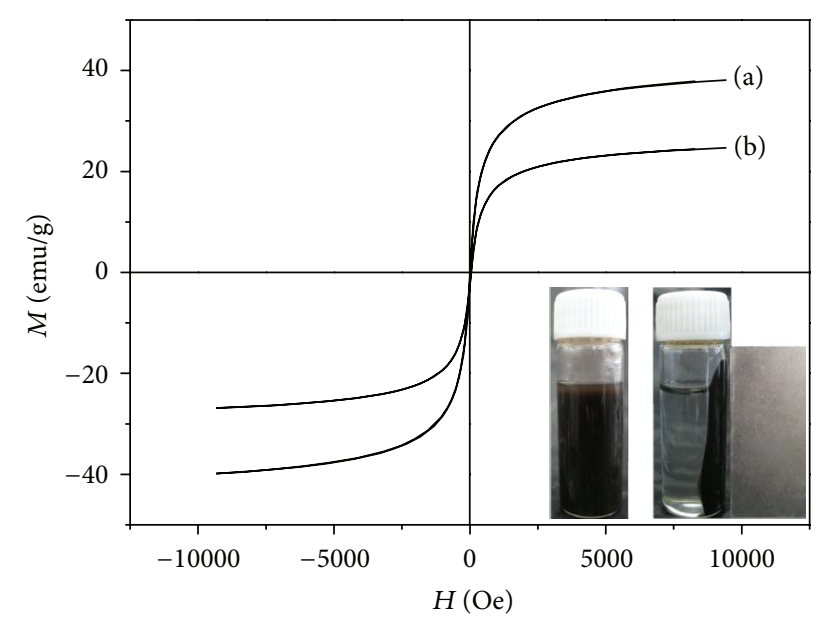

FIGURE 4: Room-temperature magnetization hysteresis loops of $\mathrm{Fe}_{3} \mathrm{O}_{4} @ \mathrm{SiO}_{2}$-CAAQ NPs (inset is the photograph of $\mathrm{Fe}_{3} \mathrm{O}_{4} @ \mathrm{SiO}_{2}$ CAAQ NPs suspension with a magnet).

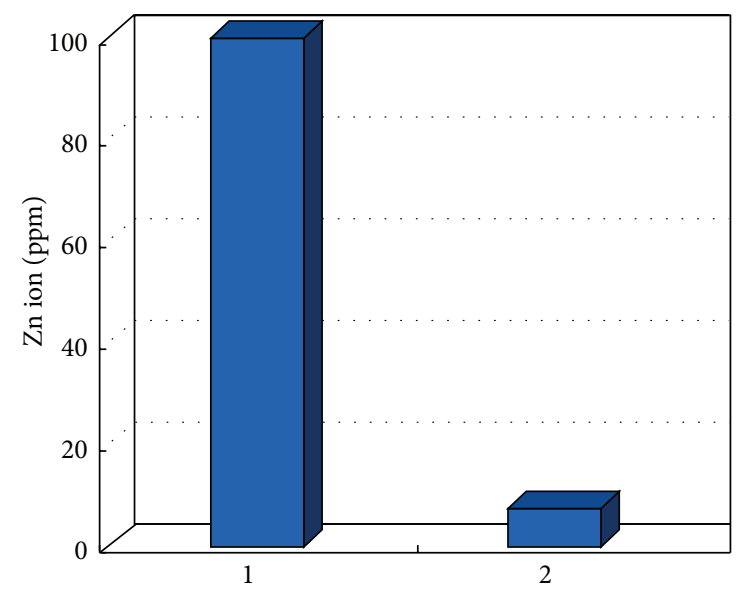

Figure 5: Removal-efficiency histograms of $\mathrm{Zn}^{2+}$ on $\mathrm{Fe}_{3} \mathrm{O}_{4} @ \mathrm{SiO}_{2}$ CAAQ surface: concentration of $\mathrm{Zn}^{2+}$ (1) before and (2) after $\mathrm{Fe}_{3} \mathrm{O}_{4} @ \mathrm{SiO}_{2}$-CAAQ treatment. The initial concentration of $\mathrm{Zn}^{2+}$ is $100 \mathrm{ppm}$, the volume of $\mathrm{Zn}^{2+}$ is $10 \mathrm{~mL}$, the weight of nanoparticles is $20 \mathrm{mg}$, the adsorption time is $12 \mathrm{~h}$, and the temperature is $25^{\circ} \mathrm{C}$.

sample solution. The accurate removal response was observed from $100 \mathrm{ppm}$ to as low as $7.63 \mathrm{ppm}$ at room temperature and the removal efficiency could reach $92.37 \%$. The effective adsorption capacity implied that the proposed method for $\mathrm{Zn}^{2+}$ removal at room temperature was a successful attempt.

The sensitivity of the $\mathrm{Fe}_{3} \mathrm{O}_{4} @ \mathrm{SiO}_{2}-\mathrm{CAAQ} N P$ s to $\mathrm{Zn}^{2+}$ in $\mathrm{C}_{2} \mathrm{H}_{3} \mathrm{~N}$ was investigated by UV-vis spectra (Figure 6). With $\mathrm{Zn}^{2+}$ attachment, the $\mathrm{Fe}_{3} \mathrm{O}_{4} @ \mathrm{SiO}_{2}$-CAAQ NPs exhibited two evident absorption peaks at about 374 and $301 \mathrm{~nm}$, and the intensity of absorption gradually enhanced upon binding with increasing the concentration of $\mathrm{Zn}^{2+}$, which was attributed to the formation of a $\mathrm{Fe}_{3} \mathrm{O}_{4} @ \mathrm{SiO}_{2}-\mathrm{CAAQ}+\mathrm{Zn}^{2+}$ complex.

Figure 7 depicted the $\mathrm{Zn}^{2+}$-selective sensing mechanism and fluorescent change of $\mathrm{Fe}_{3} \mathrm{O}_{4} @ \mathrm{SiO}_{2}$-CAAQ with

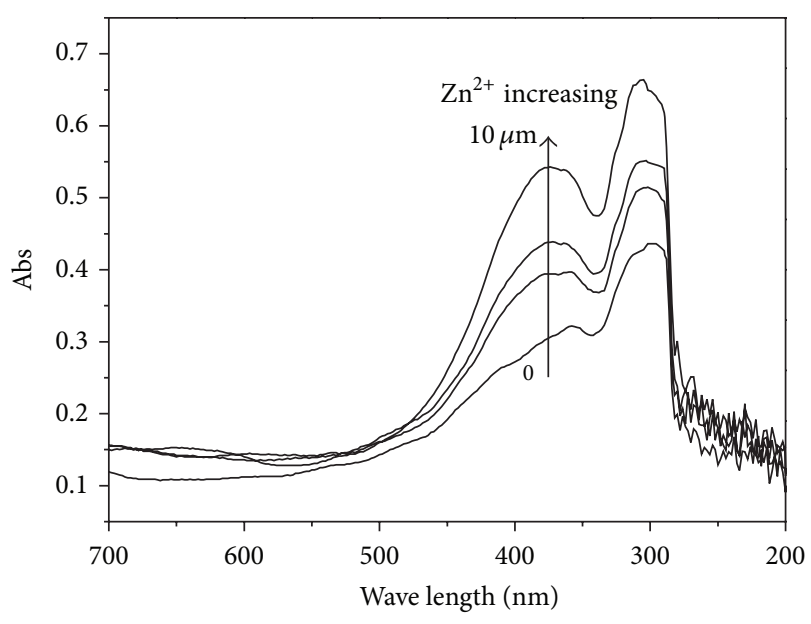

Figure 6: UV-vis curves of the $\mathrm{Fe}_{3} \mathrm{O}_{4} @ \mathrm{SiO}_{2}$-CAAQ NPs $(0.3 \mathrm{~g} / \mathrm{L})$ in $\mathrm{C}_{2} \mathrm{H}_{3} \mathrm{~N}$ with various amounts of $\mathrm{Zn}^{2+}(0-10 \mu \mathrm{M})$.

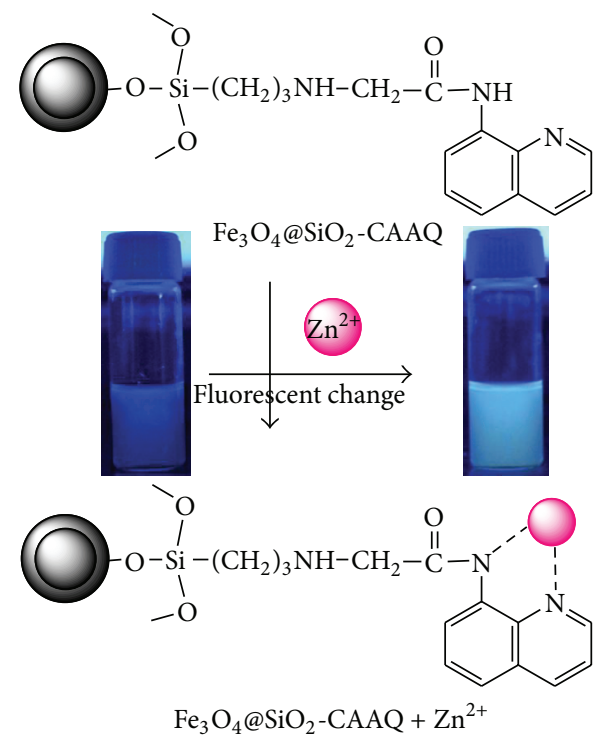

FIgUre 7: The complexation model of $\mathrm{Fe}_{3} \mathrm{O}_{4} @ \mathrm{SiO}_{2}-\mathrm{CAAQ}$ and $\mathrm{Zn}^{2+}$ (inset is the fluorescent change of $\mathrm{Fe}_{3} \mathrm{O}_{4} @ \mathrm{SiO}_{2}-\mathrm{CAAQ}(0.3 \mathrm{~g} / \mathrm{L}$ ) with $\mathrm{Zn}^{2+}(100 \mu \mathrm{M})$ in $\mathrm{CH}_{3} \mathrm{CN}$ media).

$\mathrm{Zn}^{2+}$. The considerable blue-yellow emission of the acetonitrile solution can easily be observed by naked eye for $\mathrm{Fe}_{3} \mathrm{O}_{4} @ \mathrm{SiO}_{2}-\mathrm{CAAQ}$ upon binding $\mathrm{Zn}^{2+}$ by comparison with that of only $\mathrm{Fe}_{3} \mathrm{O}_{4} @ \mathrm{SiO}_{2}$-CAAQ. The fluorescence enhancement of $\mathrm{Fe}_{3} \mathrm{O}_{4} @ \mathrm{SiO}_{2}-\mathrm{CAAQ}+\mathrm{Zn}^{2+}$ could be attributed to the induction from $\mathrm{Zn}^{2+}$ attachment. Namely, when the $\mathrm{Fe}_{3} \mathrm{O}_{4} @ \mathrm{SiO}_{2}$-CAAQ was selectively coordinated with metal ions, the fluorescence from $\mathrm{Fe}_{3} \mathrm{O}_{4} @ \mathrm{SiO}_{2}$-CAAQ was modified appropriately by the metal ions. Our previous efforts in our group were made to demonstrate that $\mathrm{Cu}^{2+}$ with $\mathrm{Fe}_{3} \mathrm{O}_{4} @ \mathrm{SiO}_{2}$-CAAQ treatment could result in fluorescence quenching when other metal ions $\left(\mathrm{Ag}^{+}, \mathrm{Hg}^{2+}, \mathrm{Ni}^{2+}, \mathrm{Co}^{2+}\right.$, $\mathrm{Mn}^{2+}, \mathrm{Pb}^{2+}, \mathrm{Cr}^{3+}$, and $\left.\mathrm{Fe}^{3+}\right)$ caused no observable fluorescent changes. 


\section{Conclusions}

The $\mathrm{Fe}_{3} \mathrm{O}_{4}$ NPs coated with silica nanoparticles were prepared, and an attempt had been made that the $\mathrm{Fe}_{3} \mathrm{O}_{4} @ \mathrm{SiO}_{2}$ NPs were modified by 8 -chloroacetylaminoquinoline. The functionalized $\mathrm{Fe}_{3} \mathrm{O}_{4} @ \mathrm{SiO}_{2} \mathrm{NPs}$ as a fluorescent sensor for detection of $\mathrm{Zn}^{2+}$ were available. Meanwhile, the hybrid fluorescent material showed an efficient removal of $\mathrm{Zn}^{2+}$ (92.37\%) and exhibited excellent magnetic properties for further biological and environmental applications. Aside from the applications for the detection of $\mathrm{Zn}^{2+}$, owing to the require of the diversity and controllable ability of functional molecules on surface of nanoparticles, our efforts are concentrated to extend current work to applications in selective detection and removal of heavy-metal ions such as $\mathrm{Hg}$ (II), $\mathrm{Pb}$ (II), $\mathrm{Cu}$ (II), and Cd (II).

\section{Conflict of Interests}

The authors declare that they have no conflict of interests.

\section{Acknowledgments}

Financial support of this work from NSFC (50903041), Natural Science Foundation of Yunnan Province (2009CD026 and 2010CA019), and Inspection and Quarantine of the People's Republic of China (2009QK406) was gratefully acknowledged.

\section{References}

[1] K. H. Falchuk, "The molecular basis for the role of zinc in developmental biology," Molecular and Cellular Biochemistry, vol. 188, no. 1-2, pp. 41-48, 1998.

[2] W. Maret, C. Jacob, B. L. Vallee, and E. H. Fischer, "Inhibitory sites in enzymes: zinc removal and reactivation by thionein," Proceedings of the National Academy of Sciences of the United States of America, vol. 96, no. 5, pp. 1936-1940, 1999.

[3] H. H. Sandstead, "Zinc is essential for brain development and function," The Journal of Trace Elements in Experimental Medicine, vol. 16, no. 4, pp. 165-173, 2003.

[4] J. A. Duce, A. Tsatsanis, M. A. Cater et al., "Iron-export ferroxidase activity of $\beta$-amyloid precursor protein is inhibited by Zinc in Alzheimer's disease," Cell, vol. 142, no. 6, pp. 857-867, 2010.

[5] E. M. Alvarez, R. S. Otero, A. H. Ameijeiras, A. M. L. Real, and J. L. L. Garcia, "Effects of aluminum and zinc on the oxidative stress caused by 6-hydroxydopamine autoxidation: relevance for the pathogenesis of Parkinson's disease," Biochimica et Biophysica Acta, vol. 1586, no. 2, pp. 155-168, 2002.

[6] T. Liu and S. Liu, "Responsive polymers-based dual fluorescent chemosensors for $\mathrm{Zn}^{2+}$ ions and temperatures working in purely aqueous media," Analytical Chemistry, vol. 83, no. 7, pp. 2775-2785, 2011.

[7] D. Dong, X. Jing, X. Zhang, X. Hu, Y. Wu, and C. Duan, "Gadolinium (III)-fluorescein complex as a dual modal probe for MRI and fluorescence zinc sensing," Tetrahedron, vol. 68, pp. 306-310, 2012.

[8] A. Helal, M. Harun, M. Rashid, C. H. Choi, and H. S. Kim, "New regioisomeric naphthol-substituted thiazole based ratiometric fluorescence sensor for $\mathrm{Zn}^{2+}$ with a remarkable red shift in emission spectra," Tetrahedron, vol. 68, pp. 647-653, 2012.

[9] P. Ashokkumar, V. T. Ramakrishnan, and P. Ramamurthy, "Photoinduced electron transfer (PET) based $\mathrm{Zn}^{2+}$ fluorescent probe: transformation of turn-on sensors into ratiometric ones with dual emission in acetonitrile," The Journal of Physical Chemistry A, vol. 115, pp. 14292-14299, 2011.

[10] Z. Xu, J. Yoon, and D. R. Spring, "Fluorescent chemosensors for $\mathrm{Zn}^{2+}$," Chemical Society Reviews, vol. 39, no. 6, pp. 1996-2006, 2010.

[11] Z. Li, M. Yu, L. Zhang et al., "A "switching on" fluorescent chemodosimeter of selectivity to $\mathrm{Zn}^{2+}$ and its application to MCF-7 cells," Chemical Communications, vol. 46, no. 38, pp. 7169-7171, 2010.

[12] A. E. Lee, M. R. Grace, A. G. Meyer, and K. L. Tuck, "Fluorescent $\mathrm{Zn}^{2+}$ chemosensors, functional in aqueous solution under environmentally relevant conditions," Tetrahedron Letters, vol. 51, no. 8, pp. 1161-1165, 2010.

[13] M. Li, H. Lu, R. Liu, J. Chen, and C. Chen, "Turn-on fluorescent sensor for selective detection of $\mathrm{Zn}^{2+}, \mathrm{Cd}^{2+}$, and $\mathrm{Hg}^{2+}$ in water," The Journal of Organic Chemistry, vol. 77, pp. 3670-3673, 2012.

[14] Y. Ding, Y. Xie, X. Li, J. P. Hill, W. Zhang, and W. Zhu, "Selective and sensitive "turn-on" fluorescent $\mathrm{Zn}^{2+}$ sensors based on diand tripyrrins with readily modulated emission wavelengths," Chemical Communications, vol. 47, no. 19, pp. 5431-5433, 2011.

[15] J. Kim, Y. Piao, and T. Hyeon, "Multifunctional nanostructured materials for multimodal imaging, and simultaneous imaging and therapy," Chemical Society Reviews, vol. 38, no. 2, pp. 372390, 2009.

[16] A. Quarta, R. D. Corato, L. Manna et al., "Multifunctional nanostructures based on inorganic nanoparticles and oligothiophenes and their exploitation for cellular studies," Journal of the American Chemical Society, vol. 130, no. 32, pp. 10545-10555, 2008.

[17] R. Bardhan, N. K. Grady, J. R. Cole, A. Joshi, and N. J. Halas, "Fluorescence enhancement by au nanostructures: nanoshells and nanorods," ACS Nano, vol. 3, no. 3, pp. 744-752, 2009.

[18] J. Gao, H. Gu, and B. Xu, "Multifunctional magnetic nanoparticles: design, synthesis, and biomedical applications," Accounts of Chemical Research, vol. 42, no. 8, pp. 1097-1107, 2009.

[19] X. Zhang, H. Niu, Y. Pan, Y. Shi, and Y. Cai, "Modifying the surface of $\mathrm{Fe}_{3} \mathrm{O}_{4} / \mathrm{SiO}_{2}$ magnetic nanoparticles with $\mathrm{C}_{18} / \mathrm{NH}_{2}$ mixed group to get an efficient sorbent for anionic organic pollutants," Journal of Colloid and Interface Science, vol. 362, no. 1, pp. 107-112, 2011.

[20] M. Shi, Y. Liu, M. Xu, H. Yang, and C. Wu, "Core/shell $\mathrm{Fe}_{3} \mathrm{O}_{4} @ \mathrm{SiO}_{2}$ nanoparticles modified with $\mathrm{PAH}$ as a vector for EGFP plasmid DNA delivery into HeLa cells, macromol," Bioscience, vol. 11, pp. 1563-1569, 2011.

[21] Y. Deng, D. Qi, C. Deng, X. Zhang, and D. Zhao, "Superparamagnetic high-magnetization microspheres with an $\mathrm{Fe}_{3} \mathrm{O}_{4} @ \mathrm{SiO}_{2}$ core and perpendicularly aligned mesoporous $\mathrm{SiO}_{2}$ shell for removal of microcystins," Journal of the American Chemical Society, vol. 130, no. 1, pp. 28-29, 2008.

[22] P. Kluth, C. S. Schnohr, O. H. Pakarinen et al., "Fine structure in swift heavy ion tracks in amorphous $\mathrm{SiO}_{2}$," Physical Review Letters, vol. 101, no. 17, Article ID 175503, 2008.

[23] C. R. Li, A. L. Ji, L. Gao, and Z. X. Cao, "Stressed triangular tessellations and fibonacci parastichous spirals on $\mathrm{Ag}$ core $/ \mathrm{SiO}_{2}$ shell microstructures," Advanced Materials, vol. 21, no. 45, pp. 4652-4657, 2009. 
[24] H. Chen, C. Deng, and X. Zhang, "Synthesis of $\mathrm{Fe}_{3} \mathrm{O}_{4} @ \mathrm{SiO}_{2} @ \mathrm{PMMA}$ core-shell-shell magnetic microspheres for highly efficient enrichment of peptides and proteins for MALDI-ToF MS analysis," Angewandte Chemie - International Edition, vol. 49, no. 3, pp. 607-611, 2010.

[25] X. Kong, Y. Chen, Z. Yang, S. Wang, and Y. Zhou, "A highly sensitive and efficient functionalized magnetic chemosensor for $\mathrm{Cu}^{2+}$ removal," Physics Procedia, vol. 25, pp. 2125-2130, 2012.

[26] Y. Zhou, S. Wang, Y. Xie et al., "1, 3-Dipolar cycloaddition as a general route for functionalization of $\mathrm{Fe}_{3} \mathrm{O}_{4}$," Nanotechnology, vol. 19, no. 17, Article ID 175601, 2008. 

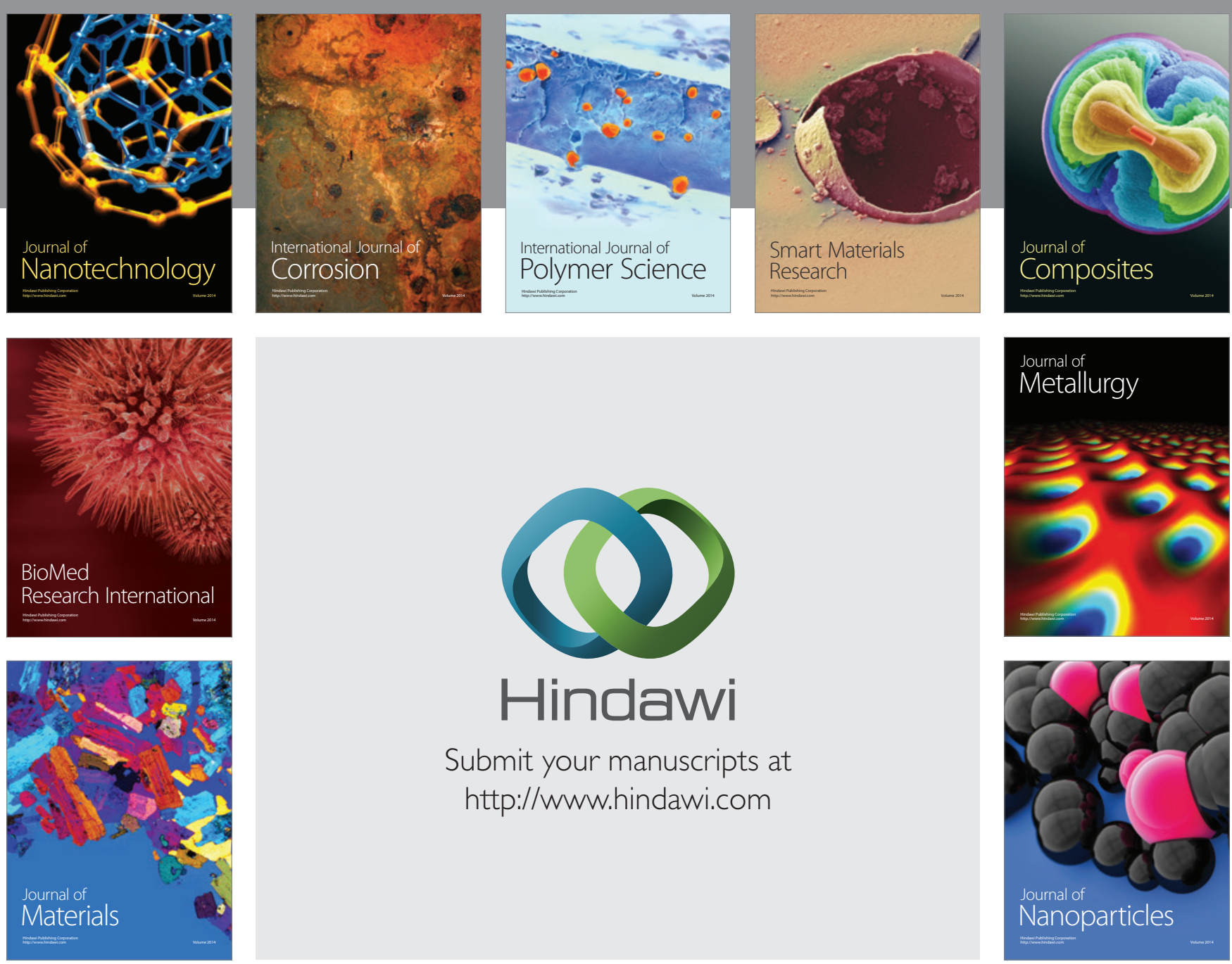

Submit your manuscripts at http://www.hindawi.com
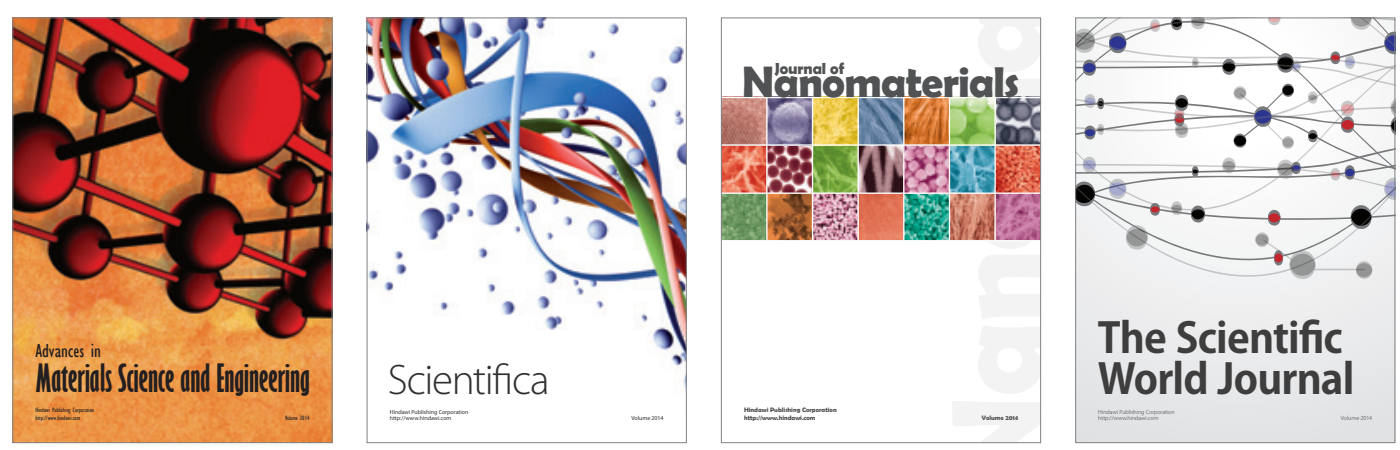

\section{The Scientific World Journal}
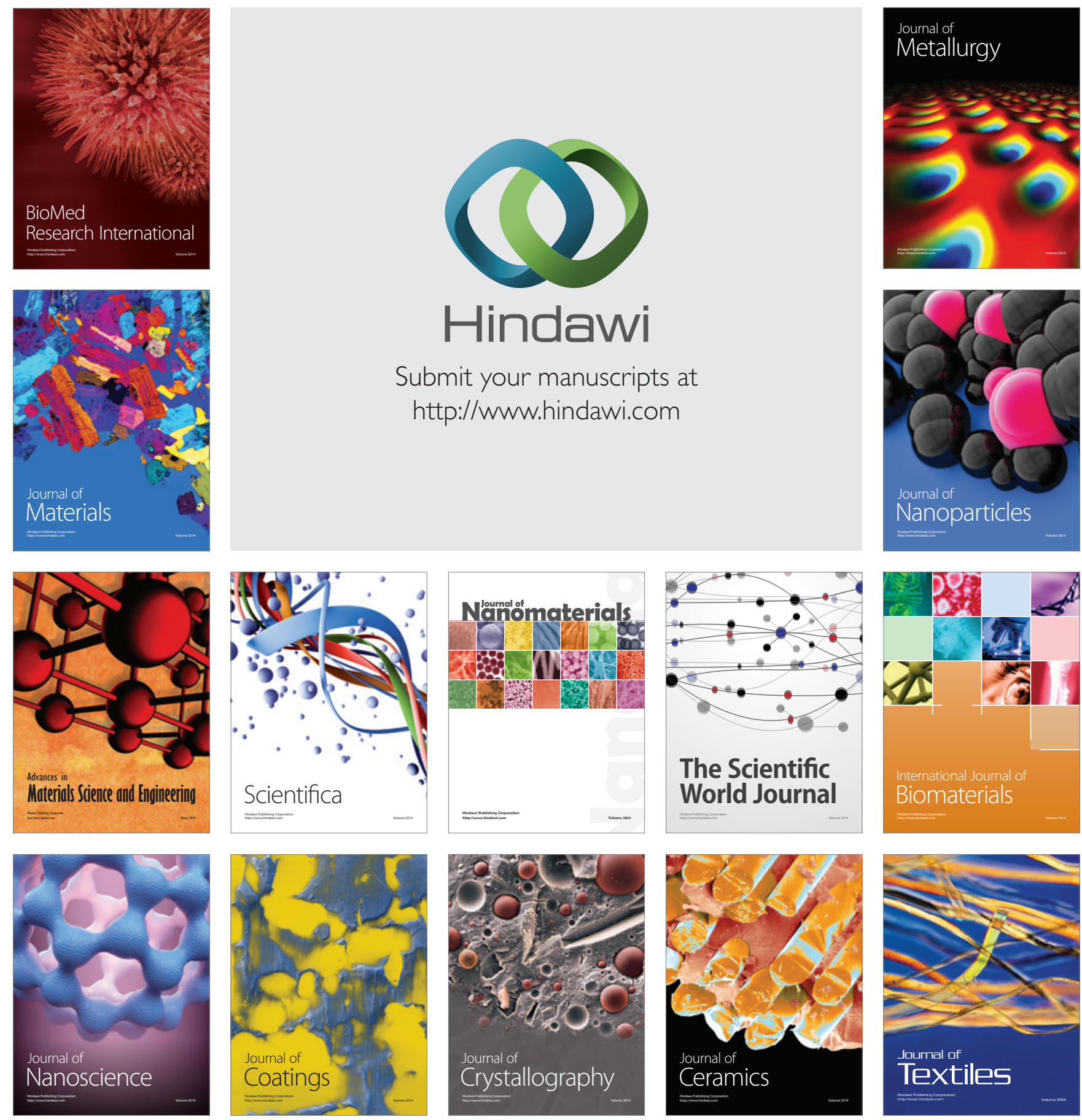